\title{
Indirect Antiglobulin Test
}

National Cancer Institute

\section{Source}

National Cancer Institute. Indirect Antiglobulin Test. NCI Thesaurus. Code C91372.

A test that uses Coombs' reagent to detect the presence of anti-erythrocyte antibodies in serum. 